\title{
Grants and Acquisitions
}

\section{Cornell University has received a} one-year grant of $\$ 799,085$ from the National Science Foundation (NSF) to develop a proposed architecture for a new online library for science education. The award is part of a $\$ 13.5$ million NSF initiative to create a National Science, Mathematics, Engineering and Technology Education Digital Library (NSDL). NSF is targeting the fall of 2002 for launch of a completed NSDL library system.

\section{The University of California, San Francisco}

(UCSF), has been awarded $\$ 15$ million by the American Legacy Foundation to establish permanent Internet access to 40 million pages of once-secret tobacco industry documents and to develop a center for scholarly study of the material. Most of the documents have been obtained through litigation led by state attorneys general. The new online documents library is considered critical to continued research in this field since the tobacco industry can remove existing documents from the Internet in 2010 under the terms of the 1998 Master Settlement Agreement between the industry and 46 state attorneys general. Legacy is the national foundation created in March 1999 as a result of the tobacco settlement agreement. The library's current Tobacco Control Archives can be found at http://nww library.ucsf.edu/ tobacco/.

\section{April 1 deadline for museum- Hbrary grant}

The Institute of Museum and Library Services will award grants to support projects that demonstrate how museums and libraries can work together to expand their services to the public. Either the museum or the library may be the lead applicant and may apply for up to $\$ 500,000$. Applications are due April 1, 2001. For more information, visit http://www.imls.gov/ grants/museum/mus_nlgm.asp.

\section{The Golda Meir Library at the University} of Wisconsin, Milwaukee, has received a $\$ 2,000$ grant from the Theodore and Anna Grollman Fund. The gift will enable the library to provide immediate preservation treatment for the most fragile German-language items in the American Geographical Society Collection. These materials date from the late 1800 s through the early part of the 20th century. They cover topics such as cartography and geology; pre-World War I history; geology, geography, and ethnography of German regions, cities, and colonies; geography and ethnography of Middle Europe at the turn of the 20th century; and German folk, customs, and costume history. The highly acidic content of the paper on which these materials were originally printed has caused significant deterioration.

\section{Rowan University has received a}

$\$ 2.5$ million gift from Keith and Shirley Campbell family of Salem County, New Jersey, to fund an endowment for the library and establish a professorial chair in the College of Business. Both gifts were given to the university in the form of stock. Keith Campbell is the chairman of the board of trustees at Rowan University. For a portion of time, the funds from this endowment and the expected state match will be used to help purchase a home for the president of the university and augment the library budget. Once the house is paid for, it is expected that an endowment of at least $\$ 1.5$ million will be available to support the library in perpetuity

\section{Acquisitions}

\section{Robert James Waller Jr., author of The}

Bridges of Madison County, named his alma mater Indiana University as the recipient of an estate gift with an estimated value well into the seven-figure range. Waller's gift will recognize four areas of the university: a bequest to the School of Music will even- 
tually establish the Robert J. Waller Sr, and Robert J. Waller Jr. Chair in Jazz Studies; the Kelley School of Business will receive a bequest to name the courtyard in the Corporate and Graduate Center; the University Libraries will receive a bequest of copyrights to all of his literature, art, and music; and the Research and University Graduate School will receive a bequest of Waller's ranch in Texas for preservation and research.

\section{A major archive of artist Benjamin}

West has been acquired by the Historical Society of Pennsylvania. The archive consists of 20 linear feet of material from the collections of professors Allen Staley and Helmut von Erffa (1900-97), both Benjamin West scholars. Included in the collection are works in the catalog-The Paintings of Benjamin West (Yale University Press, 1986), files on works rejected as West attributions, correspondence about possible West attributions, notes on the book, and miscellaneous items that did not make it into the original West catalog. The archive is a gift from Staley and the Barra Foundation, Inc.

\section{A set of William Maxwell's final letters}

have been acquired by the University of Illinois at Urbana-Champaign from novelist John Updike. The set consists of eight letters written or received by Maxwell just prior to his death (1908-2000). It has been added to the William Maxwell Collection, an extensive body of manuscripts and materials donated to the library by Maxwell in 1995. Maxwell, a 1930 University of Illinois graduate, was a novelist, short story writer, and legendary fiction editor. He worked at The New Yorker magazine (1936-76), where he provided editorial guidance to John Updike and other famous writers, including John Cheever, J. D. Salinger, Eudora Welty, Tennessee Williams, and others.

\section{The University of Georgia (UGA) has}

completed a project to preserve television programs documenting African-American history. More than 1,100 television programs dating from 1949 to the present that document African-American history and culture have been cataloged, preserved, and made accessible to faculty, students, researchers and the public at the UGA Libraries' Brown Media Archives and Peabody Awards Collection. This project was funded in part by a $\$ 96,590$ grant from the National Endowment for the Humanities with additional support provided by the libraries. To be included in this project, a nonfiction program had to focus on a topic relevant to African Americans or feature an African-American reporter or host; entertainment and children's programs required at least one African-American character, performer, or guest. Included in this project were such varied programs as a 1949 local special on Baltimore's slums; national and local news programs from the civil rights era; recent Peabody Award-winning documentaries on Malcolm $\mathrm{X}$ and Henry Aaron; and several programs on Martin Luther King Jr. For a full listing of titles and more information about the project see the project Web site at http://www. libs.uga.edu/peabody/wlcmafam.html.

\section{A collection for theology and religious}

studies has been acquired by Mount Aloysius College in Cresson, Pennsylvania. The Ecumenical Studies Collection of more than 10,000 volumes was given to the by the Rev. Gerald Myers of Hooversville, Pennsylvania. For the last 35 years, Myers has collected titles covering all areas of the Judeo-Christian tradition, including supporting material with a historical and biographical emphasis. A significant part of the collection is devoted to primary religious sources and their explication. Myers continues to add new titles, and it is his desire, as well as the college's, to see the Ecumenical Studies Collection become a focal point of dialogue among all denominations. Copy cataloger Joan Mix has cataloged more than 7,500 volumes in just nine months and these can be accessed through the library's nonline catalog, Mountlink, which will soon be available on the Internet.

Ed. note: Send your news to: Grants \& Acquisitions, C\&RL News, 50 E. Huron St., Chicago, IL 60611-2795; e-mail: ayoung@ala.org. 